\title{
Repatriation and restitution of Holocaust victims in post-war Denmark
}

\author{
SOFIE LENE BAK
}

\begin{abstract}
ewish Holocaust survivors faced severe economic and emotional difficulties on returning home

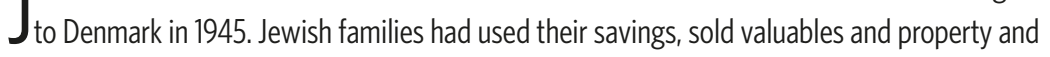
obtained improvised private loans in order to finance their escape to Sweden. Homes, businesses and property had been subject to theft and abuse. During and after the German occupation, however, Danish authorities worked to mitigate and ameliorate the consequences of Nazi persecution and the Danish government implemented one of the most inclusive and comprehensive restitution laws in Europe, taking into account Jewish victims of deportation as well as victims of exile. The restitution process underlines the dedication of the Danish authorities to the reintegration of the Jewish community and their interest in allaying potential ethnic conflict. Furthermore, the process is a remarkable - but overlooked - missing link between the social reforms of the 1930s and the modern Danish welfare state.
\end{abstract}

Amidst the horrors of the Holocaust, the case of Denmark is exceptional, and celebrated for the fact that $9^{8}$ per cent of the Jewish population survived persecution, the vast majority of them taking refuge in Sweden. The story of the rescue of the Danish Jews is a truly world-famous chapter of Danish history - possibly its only one. Research studies, as well as media reports and works of fiction have been, and continue to be, fuelled by a fascination with the story of the rescue in Denmark, where survival was the norm, as was a response of solidarity and aid for the Jews amongst the population. Yet historiography is almost exclusively limited to events which occurred in the autumn of I943, when 95 per cent of the Jews in Denmark were rescued and taken to safety in Sweden. Little attempt has been made to expand the framework of historiography to include the experience of exile as well as the return of the Danish Jews and the aftermath of the Holocaust. But how can we measure the impact of the Holocaust on the victims and on society as a whole without knowledge of the effects of exile, deportation and repatriation and the long-lasting effects of trauma? 1

1 The following is based on Bak 2or I and Bak 2012. 


\section{The round-up}

On October I, I943, the telephone lines in Copenhagen were cut off. Columns of open platform lorries manned by German police drove out onto the streets from the German Headquarters in City Hall Square. The German police brought along detailed lists of the addresses of Jewish families and were assisted by Danes who knew the locality, among them volunteers from the Waffen-SS, home in Denmark on furlough. At least I, 500 German policemen were available for the round-up of the Danish Jews. The aim was a surprise attack on the Danish Jewish community, which consisted of approximately 8,000 individuals mostly living within the environs of the capital. Within three hours 198 had been arrested in Copenhagen. By the morning of October 2, the total number who had been arrested in the country during the round-up was 28r. Despite the heavy police presence less than 5 per cent of the Jews had been arrested; the Jewish families had already left their homes in alarm following a warning that had come from high up in the German hierarchy. ${ }^{2}$

Even more surprisingly, the available German police force was not mobilised to persecute the Jews after the round-up on October I. The German army remained on the whole passive, despite receiving orders to support the police. In the German headquarters in Copenhagen, pursuit of the fleeing Jews was assigned to a small group of men in the German security police department IV-B-4, which dealt with Jewish issues. They were completely dependent on Danish informers. The limited resources assigned to the persecution affected the results. The total number of the arrests after the round-up of October I was I97.

As a consequence, 472 people were deported from Denmark because of their Jewish descent. 470 were sent to KZ Theresienstadt, north of Prague. During the course of the I 9 months they spent in the camp, 53 died. Yet according to a deal agreed between the Third Reich's Plenipotentiary in Denmark, Werner Best and Adolf Eichmann, in charge of the mass deportation, all Jews deported from Denmark were to stay in the Theresienstadt camp and were not selected for transport to the extermination camps. Only one Dane was deported on from Theresienstadt to Auschwitz, presumably by mistake. From February I 944 the prisoners were allowed to receive food parcels from Denmark and

2 For a lengthy discussion of the warning from Georg Ferdinand Duckwitz, the shipping expert at the German Legation, and his relationship to the Plenipotentiary in Denmark, Werner Best, see Bak 200 I and Kirchhoff 2013. 
the remaining prisoners were liberated from the camp in April I 945 and conveyed to Sweden in a joint operation by the Swedish Red Cross and the Danish authorities.

In Sweden they were united with family and friends. In the course of just a few weeks in October 1943, 7,742 persons had fled to Sweden, including children of mixed marriages and Gentile spouses; all victims of persecution by the Germans.

\section{Safeguarding property during the occupation}

On 3 October 1943 - two days after the round-up of Danish Jews - the municipality of Copenhagen dispatched a group of civil servants to the Copenhagen synagogue:

The Germans had used it as a collection point during the round-up of the Jews and it still exhibited the signs of this. Prayer shawls were thrown over the seats of the chairs and prayer books were spread over the floor. On the elevated area the floor was strewn with cigarette butts, and the trustees' top hats, which were usually kept in a cupboard in the entrance, had been used as footballs and kicked across the floor and underneath the rows of benches. The Social Service removed what they assessed to be of value: some Torah scrolls, various silver objects and books. These effects were moved, along with some boxes of items from the Museum of the Jewish Community, to the crypt of one of Copenhagen's old churches with the help of the Museum of Copenhagen. And from there they were delivered back to a representative of the Jewish community after the German capitulation. ${ }^{3}$

This account of the disrespectful behaviour at the synagogue is reminiscent of the behaviour of the German occupation forces all over Europe, where Jewish property was vandalized and destroyed. But it also tells of the exceptional conditions under occupation that were in effect in Denmark, where neither the destruction nor theft of Jewish property was tolerated.

The action in the synagogue was the first instance of many which were carried out by the civil servants acting under the unsuspicious name Socialtjenesten ('the Social Service'). On 2 October I 943, the municipality of Copenhagen received an unusual request from the Ministry of Welfare. The ministry requested that

3 Report dated 25 June 1946, The Social Directorate Information Service: The Social Service I 943-5, Copenhagen City Archive. 
the municipality safeguard the belongings of the Jews who had fled their homes and property. The choice of the municipal agency of the Social Service was not incidental. The agency had originally been set up in the spring of I 943 with the intention of providing shelter for people whose homes were destroyed, or had to be abandoned temporarily because of incidents of war, primarily air raids. Moreover, the agency carried out crisis planning for mass evacuations, water and food supplies. Now in October 1943 its responsibilities were extended to cover abandoned belongings and property. In the months to follow the Social Service dealt with I,970 inquiries about empty homes and other suspicious circumstances around the city. When the Social Service received an inquiry, its agents visited the residence, checked conditions and made a complete inventory of the household effects. If it was possible to retain the flat, the Social Service paid the rent for the rest of the occupation. Had the flat already been rented out again, or circumstances indicated that it was being sub-let (for example, if the rent was high), all personal property and furniture were put in storage. Contracts with trustees for property and businesses were established with neighbours, relatives and employees preventing thefts and larceny. In all the Social Service paid rent and all other costs for 97 flats, while storage was provided for the goods of 350 households through municipal efforts. The work of the Social Service was unique: during the German occupation a Danish public agency managed to protect the abandoned property of the Jews. The rationale behind the work of the Social Service was that the Jews should have homes to return to; no less remarkable was the fact that the arrangements were partly due to an agreement with the German authorities. Although the agreement with the German security police concerned safeguarding the property and flats of deported Jews only, the Danish authorities interpreted the agreement loosely as covering 'anyone, who because of the circumstances has deemed it necessary to remove themselves out of harm's way, whether in this country or abroad'. ${ }^{4}$

The flats that the Social Service inspected had only in a very few cases been vandalized by the German police. There were no cases of looting. The frequent cases of theft discovered by the Social Service were apparently carried out by other Danes.

4 Letter of ${ }_{23}$ October 1943 to the chief administrative officers in the regions in Denmark from The permanent under-secretary of the Ministry of Welfare, Archives of the Ministry of Welfare, National Archives. 


\section{Immediate needs and relief}

Denmark was liberated on 5 May 1945 after five years of German occupation, and a coalition government with equal representation from the political parties and the resistance movement assumed power on the same morning. The coalition government established a new Ministry for Special Affairs which was primarily intended to deal with the demobilisation of the resistance movement and to assist the members of the resistance in their return to normal life. 'Offices for Special Affairs' were set up in all the larger towns to carry out practical matters. A joint office for Copenhagen and its suburbs - the 'Central Office' - led the way for the rest of the country.

The Central Office for Special Affairs opened on I6 May I945 to provide immediate help, restitution and compensation for the victims of the occupation. The Central Office supplied economic assistance to meet the costs of food, rent, clothing, furniture and debt relief, in addition to immediate help to re-establish jobs and livelihood, either by supporting the re-establishment of private workshops or firms, or providing subsidies for work clothes and tools. The costs were substantial: in 1947 assistance amounted to 8.8 million Danish Crowns (DKK) in total (approx. I.I 8 million euros).

Jewish victims turned out to be a substantial proportion of the clientele taking up this assistance. A group designated 'former Jewish refugees' formed 25 per cent of all recipients of help, and included a total of 4,200 persons who received temporary economic assistance from the Central Office. The Jewish refugees were the largest single group and thus the most substantial group of recipients of help from the Central Office. The numbers indicate that on return at least half of the Danish Jews needed, and received, economic help.

\section{Displaced persons}

The Second World War had decimated the population of Europe. Millions had fled or been forcibly removed or deported across the borders of the continent. When Germany capitulated ro million people, primarily civilians forced to labour in German territories and survivors from the $\mathrm{KZ}$ camps, were categorized as 'displaced persons' (DP).

When repatriated a total of I,534 former refugees and deportees passed through a DP camp in Denmark before they were able to establish a new home. Ninety to ninety-five per cent of the residents were Jews. This means that close to one in five Jewish victims stayed in a DP camp in Denmark. 
The first camps for returned refugees in Denmark were sited in school buildings in the suburbs of Copenhagen. During the period from the end of May i 945 to May I 946 the Central Office for Greater Copenhagen managed six camps in all. Residents were housed in overcrowded dormitories in converted gyms and classrooms. At first men and women were separated. Food for the camps was delivered by the soup kitchens of the City of Copenhagen until September 1945, when the food service of the Jewish community took over. Some of the food which the city provided turned out to be wasted, 'since a great many of the residents of the camps were Orthodox Jews, and as a result, could not partake of a food service that also served pork. ${ }^{5}$ Care for the residents in the camps did include respect for special religious needs. Furthermore, financing this special service was considered a responsibility of the state, and the expenses of the Jewish Community were refunded according to a precisely agreed-on tariff. When the Central Office brought up the question of shutting down the DP camps towards the end of I 945, negotiations were initiated with the community regarding an actual takeover of the camp. The community bridled at the proposal: 'They had long ago discontinued charitable support and would prefer to avoid taking on this responsibility. 6 The Central Office did not push the question further. 'Long ago' was an overstatement. The Jewish community had actually financed and distributed poor relief until I 932, when the municipality of Copenhagen had assumed the responsibility in preparation for the social reforms. Furthermore, throughout the r 930 s economic relief and food for the Jewish refugees from Nazi Germany had been left to the Jewish community.

For many families placement in a DP camp in Denmark was the last straw. They had endured flight, exile and deportation. But to return to Denmark and end up in yet another refugee camp crushed their confidence and morale. Conditions in the camps were chaotic and nerve-racking. Quarrels, fights, vandalism, thefts and a stream of complaints were all part of life in the DP camps. The residents experienced the irritation and resentment of the local community, who wanted to use their school buildings for their children's education, and rising impatience with both the authorities and the personnel. Antisemitic

5 Food deliveries in October I 945 to the two remaining camps ran up to 8,649 DKK (I, I 59 euros), Letter to the Jewish Community 27.I I.I 945, The Central Office for Special Affairs, The Provisional Archives of Zealand.

6 Letter to the 3 rd magistrates department I 5.I.I 946, the Central Office for Special Affairs, the Provisional Archives of Zealand. 


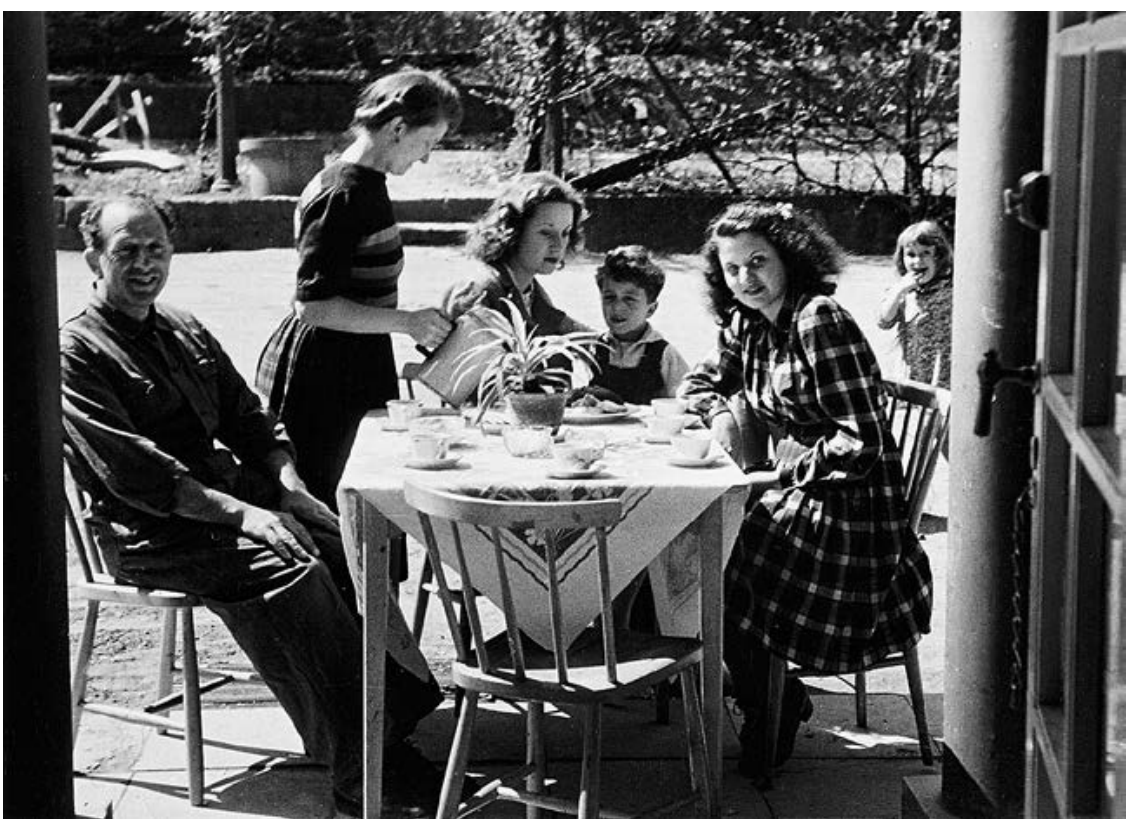

This photograph from the Danish Displaced Persons (DP) camp 'Trepilelaagen' in 1945 was taken by the The Central Office for Special Affairs to document the everyday life of the camp. The romantic impression of cosy and relaxing situations was in blatant contrast to the grievances and conflicts that characterized the camp. Photo by courtesy of The Provisional Archives of Zealand.

reactions were frequent among neighbours and personnel unfamiliar with posttraumatic behaviour. ${ }^{7}$

Even so, other staff members worked unceasingly to alleviate the troubles of the residents. They begged the municipal housing committees and the housing agency to procure flats and increasingly employed nationalistic arguments with references to the sufferings that these Danes had had to endure during the occupation. During the autumn of 1945 the DPs were moved to villas in affluent neighbourhoods in the north of Copenhagen. Although elegant in looks and surroundings, the conditions here nevertheless put strain on the privacy and family lives of the residents.

Construction activity in Greater Copenhagen was intense in the early post-war years. In the suburbs northwest of Copenhagen new flats were completed in 1946, and room was found here for the homeless families. One such 
residential neighbourhood even went under the nickname 'Little Jerusalem'. The last residents moved out of the DP camps in August of I 946 - I6 months after the liberation.

\section{Conflict}

The Central Office functioned as a mediator and support for the efforts Jews made to overcome the consequences of deportation and flight. This involved situations when the return home resulted in conflict with former friends, acquaintances, colleagues and neighbours who had either over-interpreted their power of attorney and dealt with the belongings and property of the Jews more freely than was originally intended or when there had been actual misuse and theft. This unanticipated problem was quickly resolved by providing free legal aid through Studentersamfundets retshjalp (the Legal Aid Bureau). Contrary to the routine of the Legal Aid Bureau, where only 4 per cent of all inquiries were handled by a lawyer, all cases concerning Jewish victims were evaluated by a lawyer even though only 50 per cent came to court and most ended with a settlement. Yet the cases enacted by the Legal Aid Bureau is only a fraction of the total number of civil lawsuits concerning theft and misuse which were initiated by Jews, since this service was only available to persons of limited means.

Obviously, the disagreements relating to homecoming were a painful experience for all concerned. All over Europe such conflicts occasioned displeasure and anger, not only among the accused, but also the authorities, witnesses and in the local neighbourhoods. Jews, who had never been expected to return, now demanded the recovery of their housing, property and employment. Many of these conflicts were hardly unique to returning Jews. People who had fled or been deported as a result of political activities also experienced difficulties in reestablishing themselves in Denmark. The conflicts depended to a considerable degree on whether their surroundings acknowledged the cause of their exile or imprisonment. Several witnesses describe the initial responses they encountered when they returned home to their old neighbourhood dressed in their nicest clothes in honour of the happy day. Danish society was worn down after five years of occupation. Textiles were rationed, and the Danes had been forced into resorting to incredible improvisations to maintain and renew their wardrobes. The neighbours construed the fine clothes of the returnees as the expression of a luxurious life in Sweden which had been enjoyed at an agreeable distance from occupied Denmark. Gifts from Sweden were perceived as offensive handouts. Even though such episodes may seem petty and insignificant, they were etched in memories as part of the experience of returning home. 
The Danish authorities, represented by the Central Office for Special Affairs, attempted to minimize conflicts associated with returning home. In part because the Central Office acted as a mediator, in part because the temporary help and the attempts to obtain housing and work made actual legal action - which no one desired - less than absolutely necessary. This comprehensive assistance eased the demanding transition from war to peace and assured the re-integration of the Danish Jews into Danish society. The Central Office was not abolished until October of 1947 .

\section{Compensation}

On October I, I 945 the Danish parliament passed the Lov om erstatning til besattelsestidens ofre ('Law of Compensation to the Victims of the Occupation') in recognition of a considerable need for public assistance for those people whose existence had been shattered by the events of the war. The law was primarily aimed at members of the resistance and political deportees but included 'Persons persecuted because of their descent'. 'Descent' as a concept had the linguistic and social advantage of disassociation from Nazi racist ideology - and with it the politically problematic concept of race - and it did not preclude anyone from compensation. A definition of Jews, regardless of whether halakhic, legal or racial, would have excluded some victims from seeking compensation. The compensation law did not discriminate in relation to definitions of who was a Jew. The issue was whether the person had in practice been a victim of persecution, and the reasons for flight stated by the applicants were taken at face value.

The law guaranteed compensation for death and disability due to events of war, including persecution, imprisonment, internment and deportation carried out by the Germans. Tort compensation for imprisonment, internment and deportation was paid out as a fixed amount for every week the imprisonment had lasted. In addition, the law allowed for the possibility of compensation for damage to property and support to begin or continue business activity or education as well as restoration of particularly severe losses.

In I 958, when the Compensation Board took stock, a total of I 5,640 persons had applied for compensation. A total of I I 3 million Danish Crowns (DKK) (more than I 5 million euros) had been paid out in compensation under the law. I,280 people had applied for compensation because they had been persecuted due to their descent. This number includes both men and women, but women most often only applied if they had been deported or were single parents, whereas men applied on behalf of their entire family. The total number 
of people who applied for compensation was therefore considerably higher than I,280 if other family members and children are also counted. One in four of the applications were for tort damages for deportation to Theresienstadt and 95 per cent of the applications were accepted. A total of I. I million Danish Crowns $(\mathrm{DKK})$ - close to I 50,000 euros - were paid in tort damages to the deported from Theresienstadt. To grasp the current value of these amounts, the numbers must be multiplied by a factor of $\mathrm{I} 2$.

Jewish victims were also eligible for educational assistance grants. The provision for assistance to start or continue studies was a new initiative and an important political signal to the young people who had participated in the resistance movement. Otherwise the cost of education was a private matter and made the future of young people dependent on the economic means of their parents. The compensation law gave young people access to a monthly support payment, which allowed them to manage on their own and concentrate on their studies. The applicants had to provide substantial evidence that events during the war had either delayed or hindered their education. Both deportation and exile in Sweden were recognized as delaying factors.

Seventy-five per cent of the claims made by the Jews related to theft, damage and economic loss due to flight and deportation. A total of $\mathrm{I}, 058$ persons of Jewish descent had suffered a material loss which they hoped would be covered by the compensation law. These numbers are give only a hint of the true costs of the Nazi persecution. To this number should be added all those who never became aware of the legal possibilities concerning compensation, or held back from applying because they were either ashamed to receive public assistance, were wary of public authorities, or had given up hope.

The provision for restitution of severe losses made it possible to apply for help to cover the expenses Danish Jews had borne in connection with the flight to Sweden. The law granted support for repayment of loans taken to pay for the journey and compensation for the use of one's own means - both ready money and the sale of personal effects and property. The files reveal that people literally sold everything, from furniture and carpets, grand pianos and bicycles to jewellery, silver and tools - most often not at the market rate. The average price for the illegal transport to Sweden was I,ooo DKK (Danish Crowns; I 34 euros) per person in I943; the present-day value would be 20 times that amount. By way of compensation the Danish state thus contributed to financing the flight of the Danish Jews to Sweden with an estimated sum of more than 700,000 DKK (or approx. 94,000 euros). This is a small amount in relation to what has been calculated as the total costs of the exodus, with estimates ranging from I 2 up to 20 million DKK. But it was a very important political contribution for 


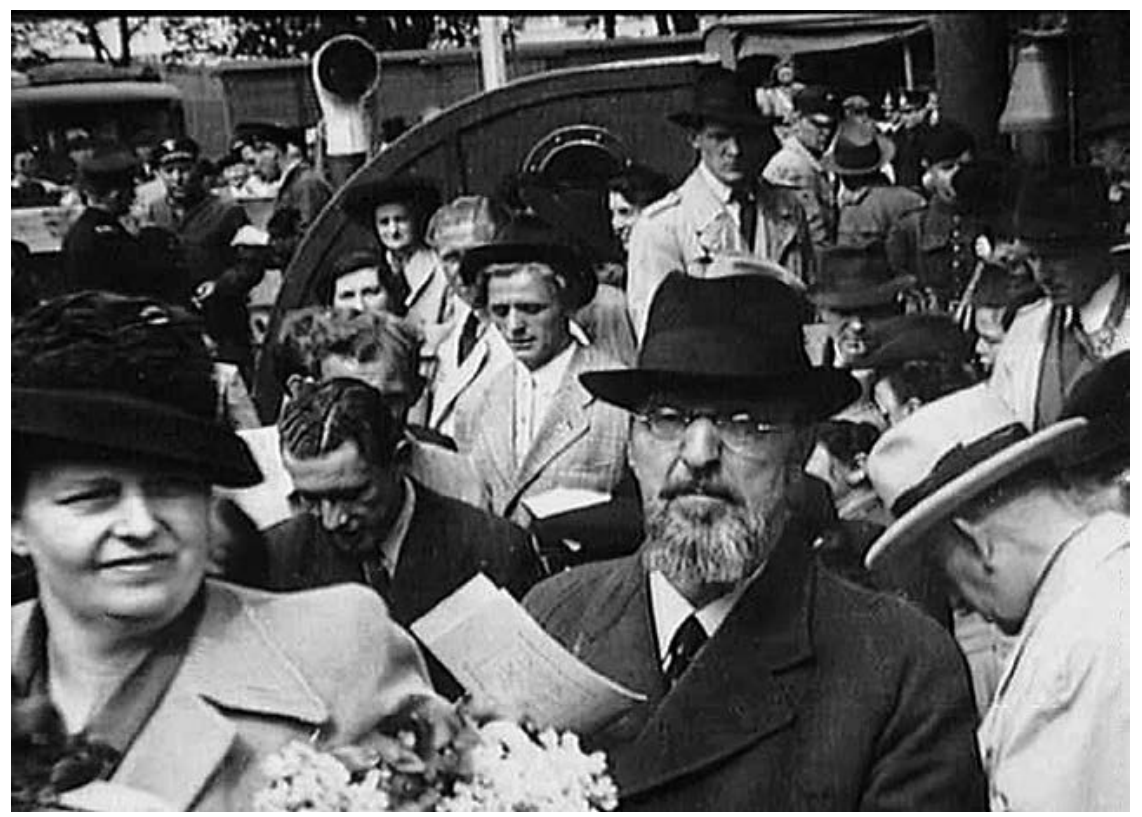

Chief Rabbi Max Friediger returns to Denmark in June 1945. The return of the Danish refugees from Sweden in the summer of 1945 was treated as a national holiday and thousands of people went to Copenhagen Harbour to greet and welcome the refugees. For the Jewish families, the festive mood was soon overshadowed by discovery of misuse and theft of their property. The Chief Rabbi had been deported to Theresienstadt and never recovered. He died in 1947. Photo by courtesy of the Museum of Danish Resistance.

Jews who had been severely affected by persecution and it put an effective end to the political and moral discussion of the legitimacy of the price of the rescue.

The total compensation paid out to Jewish victims was 2.2 million DKK (approx. 300,000 euros). The amounts were considerable - as compared to the average monthly wage for a skilled worker of 400 DKK. And the amount doesn't include invalidity pensions which are still being paid out under the provisions of the original law.

\section{Exclusions}

However, the percentage of rejections was high. A total of 45 per cent of the Jewish victims received a negative response to their application. The number is significantly higher than the total rejection rate of 22 per cent for all applications. All over Europe compensation and pension measures generally discriminated Jewish victims on the grounds of a distinction between political 
and 'arbitrary' victims, a hierarchy of victims that gave special honours and benefits to combatants (Lagrou 2005, Caetecker 2005). The Danish law was no exception.

A special 'Award of honour in acknowledgement of efforts in Denmark's fight for liberation' were granted to persons who had either participated in the resistance, or been imprisoned, interned or deported for their political activities or service in the police force. The Jewish group was ineligible for the award of honour, which resulted in a roo per cent rejection rate in this category. The distinction between 'combatants' and 'arbitrary victims' was also applied to the paragraph on lost and damaged property. Theft was only covered by the law if the applicant had been a member of the resistance, or had been imprisoned or deported. Ninety-seven per cent of the applications for compensation for theft or vandalism from Jewish victims were rejected. The legal gap resulted in embarrassing and painfully conspicuous conflicts.

Additionally, the law only covered Danish citizens. Stateless Jewish refugees were excluded from compensation whether or not they had a residence permit and regardless of their loss. Furthermore there was only access to compensation for persons who were over eighteen years of age. This was an obvious injustice. The 5 I children and young people who had been deported to Theresienstadt were not included. Though many children had become victims due to the deeds and political activities of their parents during the occupation, the children in Theresienstadt were victims in their own right but were excluded from compensation.

The law had socially lopsided effects. It was routinely checked whether the applicant had received public assistance before fleeing to Sweden. Those who were considered to have been dependent on public assistance regularly received rejections of their claims, particularly if it was found that the applicant was 'unreliable', 'unsuited to independent living' or known as a 'con artist'. Another aspect of the evaluation was how long the person had stayed in a refugee camp in Sweden. The longer the time in the camp, the more unreliable and lacking in independence the applicant was judged to be. This practice affected the weakest of the former refugees who had had difficulties in establishing themselves in Sweden.

Furthermore payments depended on an interpretation of the law's condition of 'severe economic loss'. If the possessions lost didn't represent any material value compensation were denied even though it was everything the family owned. Shabby furniture chopped for firewood and clothes torn to make polishing cloths were not considered a severe loss and not compensated. It left poor families in situations where they had lost everything and owned nothing. 
The distinction between political and 'arbitrary' victims was gradually erased. An amendment in 1973 expanded the provisions on the award of honour to include persons who had been deported because of their descent and were disabled as a result of the imprisonment. And in 1993, yet another revision of the law was passed, under which the requirement that work disability had to be reduced by at least 50 per cent in order to receive the award of honour, was revoked. The last discriminatory distinction among the victims was gone.

\section{Collective memory}

According to the national collective memory not only were the Danish Jews enthusiastically welcomed home by their countrymen, but their living conditions, housing and material status also had remained untouched despite flight and exile, thanks to the care given to their homes and possessions by fellow citizens. $^{8}$

Many families came home and found their home and property well cared for and intact. A great number of private individuals among the Danes had unselfishly and carefully kept an eye on the property of their Jewish neighbours and friends. However it was the City of Copenhagen - through the efforts of the Social Service - that was in large part responsible for this thoughtfulness. Thus public authorities played an important role in guaranteeing that Danish Jews had homes to which to return and their efforts prevented large-scale theft and larceny.

Only very few witnesses remember that they, or their families, received compensation. If the children are omitted, 77 per cent of the deportees to Theresienstadt actually received compensation from the Danish state when they came home, and to this must be added the millions paid out to cover re-establishment and the expenses of the flight. Failure to speak about compensation received was presumably due to the shame commonly attached to receipt of public assistance. Even though it was carefully emphasized that the compensation was not a social measure, accepting public assistance was at odds with the ideal of the father of a family who provides for his own. The money was perceived as a charity handout.

As the fact that a significant segment of the Danish Jews received compensation for the losses they suffered during the war was erased from individual memory it never became part of collective memory either. The explanation is 
political. To a great extent the original losses were caused by theft and misuse: families came home and found that all valuables and desirable objects had disappeared from their homes or they had had to sell furniture, jewellery, silver and shops far under the market value. They were grateful for the price they could get, which was most advantageous for the buyer. Loans and re-purchase agreements were made, which, at best, were on market terms and, at worst, were an exploitation of their wretched situation. The compensation cases involved painful conflicts, which, accompanied by a discussion of the reasonableness of the sums the Jews had been charged for crossing to Sweden, could have driven a serious wedge into Danish society. The politicians of the day wanted to avoid this at any cost. The restitution process underlines the dedication of the Danish authorities to the reintegration of the Jewish community and their interest in silencing potential ethnic conflict.

\section{The missing link}

The process of repatriation and restitution of Jewish victims in Denmark is just as extraordinary in a European context as the saving of their lives in I 943. Compared to other European countries the process which took place in Denmark is exceptional in terms of its timing, extent and inclusivity. The obvious question is why? Why was Denmark different? Was it the extraordinary national spirit of the Danes (as even serious scholars seem to suggest)? Or rather, was the aid driven by individuals dedicated to easing the plight of the Jews; or did the existing structural factors make a difference - first and foremost the legislative framework and the development of the welfare state in Denmark?

The answer is not either-or, but rather an attempt to determine the preconditions of rescue and relief during and after the Holocaust. Structural factors were decisive in determining the Danish restitution process. Not only was the legal framework behind restitution based on existing legislation. It also represented an extension and development of existing principles of social welfare. This means that the extraordinary social welfare programmes pertaining to the Second World War had a lasting impact on Danish society and facilitated a new understanding of the state's responsibilities to its citizens.

Reference to existing legislation lent legal and political legitimacy to the process. The aid provided by 'the Social Service' of the City of Copenhagen in safeguarding the homes and property of Jewish families during the exile, and the Central Office for Special Affairs providing immediate help and restitution, were both legally grounded in social welfare legislation of I933. The Law of Compensation to the Victims of the Occupation, enacted in I 945, was based on 
principles in the pre-war Law on Invalidity Pension to Casualties in Conscript Forces (1934) and wartime laws on State Insurance Subsidy to War Damage (1940) and the 'Award of honour to families of casualties and wounded on the 9th April I940' which were both enacted as a result of the German occupation in I 940 . The legal foundations of the restitution process thus reveal a continuity of social reform from the i 930 .

However, new norms were evident in practice as well as legislative principles. They reveal a development from the principle of modest aid to avoid social risk into a set of more generous and universalistic services. Thus, an investigation into the relation between the legislative and administrative measures with regard to the victims of persecution and the principles of the modern Danish welfare state is required.

International research on the relationship between war and social change and between war and changes in social policy is a well-established discipline, but Danish historiography on social history and the development of the welfare state insists on passing over the occupation years as an anomaly which curbed social development. Social changes which occurred during the occupation are referred to only as short term transitional effects (Schädler Andersen et al. 20 I2, Kolstrup 20I4). Historians concerned with the occupation history, on the other hand, largely exclude the post-war perspective and the political, social and psychological effects of the occupation have never been integrated into Danish occupation history. If the object is to investigate the long-term and permanent consequences - positive as well as negative - of the Second World War, the two disciplines should be bridged and developments which occurred during the German occupation must be considered as an integral part of the history of the Danish welfare state, just as the war years must be analysed in proportion to the social problems of the post-war period.

Firstly, the legislative and administrative measures aimed at the victims of persecution reflected an expansion of state responsibility and care for individual citizens. In Sweden during the exile, the Danish refugee administration appointed under the Danish legation concluded that running the refugee camps as a business arrangement was inappropriate to the needs of the refugees and converted the camps, whenever possible, into public institutions. Furthermore refugees, who depended on their hands (musicians as well as tailors), were exempted from hard manual labour in the refugee camps and income subsidies to families were provided without individual assessment of previous income or status. The policy of the Danish refugee administration differed not only from that of the Swedish authorities which had initially managed the camps, but also from the Norwegian Refugee Administration (Møller and Secher I 945: I I 3 ff.). 


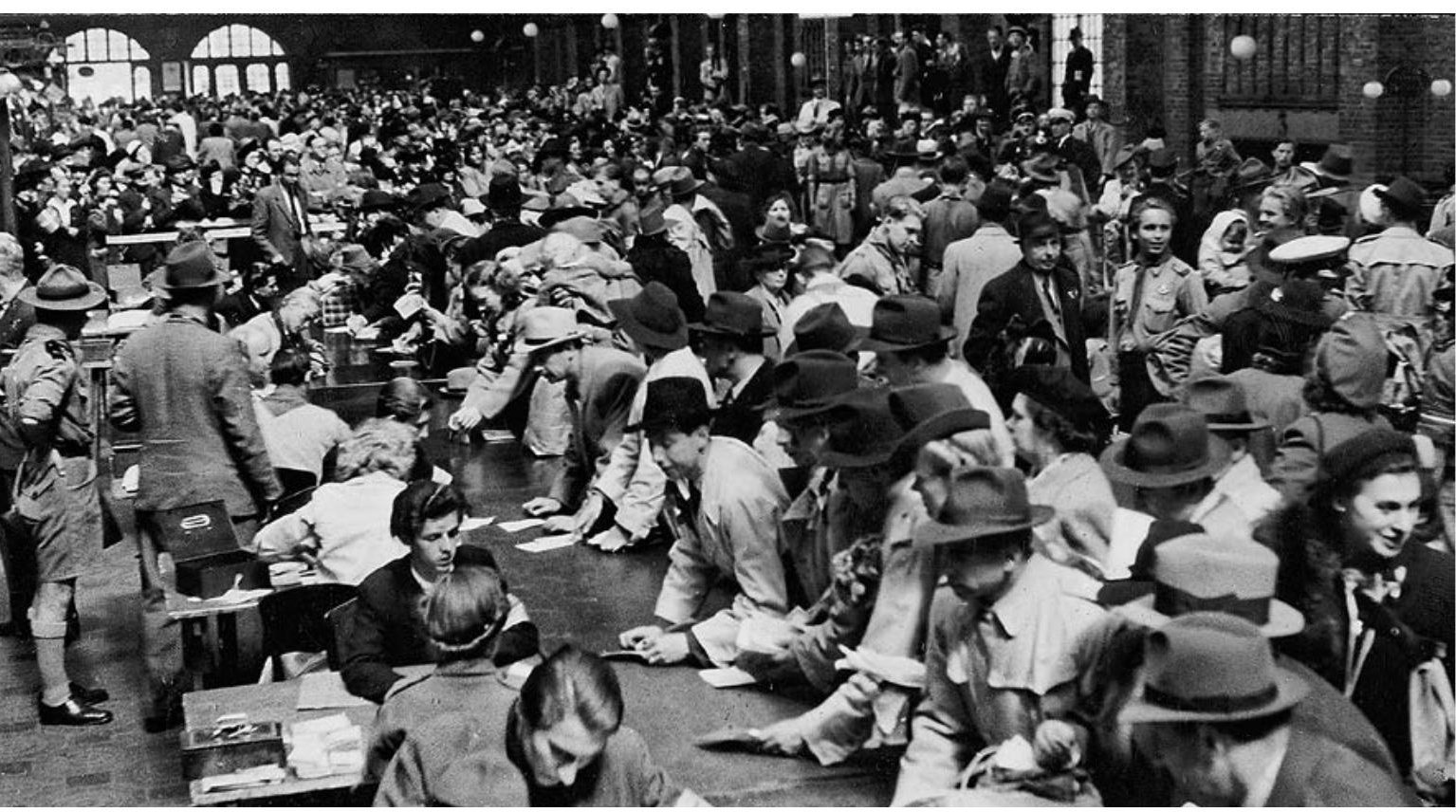

During the first weeks of June 1945, 1200 former refugees arrived from Sweden to Denmark every day. All had to be registered at the Copenhagen Central Station, where they were provided with money, rationing cards and accommodation by The Central Office for Special Affairs. Photo by courtesy of the Royal National Library.

Back in Denmark, the Social Service considered that it was its task to fully reconstruct and remedy the situation of the Jewish families, which meant doing the dishes and returning library books, and they were urged not to limit the aid according to formal or legal considerations. In other words, the remit was: anything goes. In the DP camps, respect for the religious needs of Jewish DPs not only meant delivery of kosher food from the Jewish congregation but also led to the dismissal of a leader of a DP camp who had commandeered an extra kitchen for kosher purposes without permission from his superiors.

Secondly, more generous services were provided to the victims of persecution. The Law of Compensation to the Victims of the Occupation not only specified higher rates for pensions and subsidies; the higher rates were also considered to be a precondition for rehabilitation and the victim's ability to rejoin the work force. Previously, the breakthrough for this welfare principle of rehabilitation in Denmark was considered to be The Law on Tuberculosis in I 949. By insisting on continuity, the breakthrough can now be dated to I 945 . 
Thirdly, the services were universal. There were no income or assets limitations for receiving compensation and subsidies and medical care were independent of income level. The Compensation Law even introduced a minimum income level on which basis the services were calculated - a helping hand not least to young people who had little or no income prior to their deportation. The precedent for this universal principle has previously been considered to be the reform of old-age pensions in 1956 that rescinded the legal distinction between worthy and 'unworthy' recipients and guaranteed a minimum threshold for all citizens, independent of previous income. The principle was finally abolished in general in 1960. Yet the feeling of gratitude towards the resistance that fostered the Compensation Law and the inclusion of Jewish victims suffering from the economic consequences regardless of social class neutralized the traditional distinctions between those who had no fault of their own and whose difficulties were self-inflicted and between the capable and incapable.

Another crucial distinction was finally abolished as a result of the war. Until 1932, it was the Jewish community who had financed and distributed poor relief to members of its congregation. Until I 940 economic relief and food for the Jewish refugees from Nazi Germany was left to the Jewish community. In I 945 , even though the food service of the Jewish community took over delivery to the DP camps, the state financing of this special service was never questioned. The need of the Jewish citizen was a state responsibility.

In sum, these considerations led to two remarkable conclusions. Firstly, that the form and extent of aid and assistance to the Danish Jews during and after the Holocaust is largely explained by the social reforms of the r 93 os that set out the state's responsibility for all citizens - including Jewish citizens - and by the development of the modern Danish welfare state. Secondly that the precedents for the modern principles of welfare came earlier than has been hitherto established - as they were introduced by wartime and post-war legislation.

\section{Conclusions}

The severe economic and emotional difficulties that Jewish survivors were faced with on returning home to Denmark in I 945 was only too similar to those of the Jews in the rest of Europe where homes, businesses and property had been subjected to theft and abuse.

But the prompt and inclusive state assistance provided to the Danish Jews on their return in 1945 is unique in an international context and underlines Denmark's status as the special exception during the Holocaust. Not only did the Law of Compensation include Jews as a matter of course, it also included 
the exiled Jews and the losses they had suffered in Denmark in their absence and the price they had paid for the illegal transport to Sweden. The compensations were an extension of the efforts by the Social Service and the Central Office for Special Affairs to mitigate and ameliorate the consequences of Nazi persecution. Danish politicians and authorities had attempted to prevent persecution. When it did finally occur, from the very beginning all legal means were used to ward off its results. Without the compensation payments a significant number of people would have been impoverished and would have had severe difficulties in re-establishing themselves. A most important political signal was sent, which undoubtedly increased the gratitude of the Danish Jews. The compensation payments were integral to their understanding of Danish society. It also contributed to the integration and assimilation efforts which became even more apparent in the Danish Jewish community in the post-war years. Yet the compensations were also a factor in the veil of silence that fell over the considerable economic costs of the flight.

The help had its limits. Stateless Jews and children were excluded from compensation and tort damages. But in the end the Danish state's solicitude for its Jewish citizens and its considerable contribution to the financing their escape, is nevertheless an exceptional chapter in the history of the Danish Jews.

The social welfare principles in Denmark provided a legal foundation for aid and assistance to persecuted Jews. And the experiences of civil servants in the refugee administration in Sweden, in Copenhagen City, in the offices of the Special Affairs and the Ministry of Welfare facilitated a new understanding of state responsibility and social welfare, principles that were later essential aspects of the modern Danish welfare state. Although the development was fuelled by enormous gratitude towards the resistance movement, Jewish victims benefitted from the same provisions aimed at mitigating the consequences of Nazi persecution. The result was a successful reintegration of the Jewish community into Danish post-war society.

Sofie Lene Bak is Assistant Professor in Modern History at the Saxo Institute, Copenhagen University, Denmark. She has a PhD - a dissertation on Danish antisemitism 1930-45 - from Copenhagen University (2003). She is author of several books and articles on antisemitism, Danish Jewish history and the Holocaust, including, amongst others, Nothing to Speak of: Wartime experiences of the Danish Jews 1943-1945 (2011) and most recently on the repatriation and restitution of the Danish Jews after the Holocaust Da krigen var forbi ('When the War was Over', 2012). 


\section{References}

\section{Archive sources}

\section{Copenhagen City Archive}

The Social Directorate Information Service, The Social Service I 943-5

National Archives, Copenhagen

The Compensations Board

Legal Aid Bureau

The Ministry of Welfare, Journal item I 9 I 9-67; 880, I 943

The Provisional Archives of Zealand, National Archives

The Central Office for Special Affairs

Bibliography

Bak, Sofie Lene, 200 I. Jødeaktionen oktober 1943. Forestillinger i offentlighed og forskning

(Copenhagen, Museum Tusculanum Press)

-20 I I. Nothing to Speak of: Wartime Experiences of the Danish Jerws 1943-1945

(Copenhagen, Danish Jewish Museum)

-20 I 2. Da krigen var forbi. De danske joders hjemkomst efter besattelsen (Copenhagen, Gyldendal)

Caetecker, Frank, 2005. 'The reintegration of Jewish survivors into Belgian society I 943-I 947' in The Jews are Coming Back: The Return of the Jews to their Countries of Origin after WWII, ed. David Bankier (Jerusalem, Yad Vashem), pp. 72-107

Kirchhoff, Hans, 2013. Den gode tysker. Georg Ferdinand Duckwitz - de danske jøders redningsmand (Copenhagen, Gyldendal)

Kolstrup, Søren, 2014. Den danske velferdsmodel 1891-2011. Sporskifter, motiver, drivkrafter (Frederiksberg, Frydenlund)

Lagrou, Pieter, 2005. 'Return to a vanished world: European societies and the remnants of their Jewish communities, I945-1 947' in The Jews are Coming Back: The Return of the Jews to their Countries of Origin after WWII, ed. David Bankier (Jerusalem, Yad Vashem), pp. I-25

Melchior, Marcus, I 965. Levet og oplevet. Erindringer (Copenhagen, H. Hirschsprung) — 1968. A Rabbi Remembers (New York, Lyle Stuart)

Møller, Per, and Knud Secher, I 945. De danske flygtninge i Sverige (Stockholm, Gyldendal) Schädler Andersen, Lars, Jacob Christensen, Niels Finn Christiansen, Søren Kolstrup, Jørn Henrik Petersen, and Klaus Petersen, 20 I 2. Velferdsstaten $i$ støbeskeen, 1933-1956, eds Jørn Henrik Petersen and Klaus Niels Finn Christiansen, Dansk velfærdshistorie, 3 ; University of Southern Denmark Studies in History and Social Sciences, 434 (Odense, University Press of Southern Denmark)

Steinert, Johannes-Dieter, 2010. 'Jewish survivors, displaced persons and Germans in British eyes' in Survivors of Nazi Persecution in Europe after the Second World War, eds Suzanne Bardgett et al. (London, Vallentine Mitchell), pp. I 5-34 